\title{
KRITIK M. MUSTAFA AL-A'ZAMI \\ TERHADAP IGNAZ GOLDZIHER DAN A.J. WENSINCK TENTANG AUTENSITAS HADIS SEBAGAI SUMBER ISLAM
}

\author{
Kusnadi \\ Sekolah Tinggi Ilmu Syariah (STIS) Hidayatullah Balikpapan \\ Kusnadi33@gmail.com
}

\begin{abstract}
Abstrak
Hadis secara khusus berfungsi sebagai salah satu sumber dalam penetapan hukum. Hadis baru dibukukan secara formal pada akhir abad pertama dan awal abad kedua hijrah yaitu pada masa pemerintahan Umar bin Abdul Aziz. Penelitian ini merupakan penelitian kepustakaan (library research) yang bersifat deskriptif. Maksudnya memberikan gambaran pemikiran metode kritik Muhammad Mustafa al-A'zami terhadap Ignaz Goldziher dan Wensinck. Hasil dari penelitian ini, pertama, menurut A'zami pernyataan Goldziher yang menuduh penelitian hadis yang dilakukan oleh ulama tidak dapat dipertanggungjawabkan secara ilmiah, karena lebih banyak menggunakan metode kritik sanad, dan kurang menggunakan metode kritik matan adalah tidak tepat, karena tidak ada bukti historis yang mendukung teori Goldziher dan bertentangan dengan sejarah. Kedua, Wensinck menginkari tentang Hadis akidah. Wensinck menuduh bahwa shalat baru selesai dalam bentuknya yang terakhir sesudah Nabi saw wafat. Menurut A'zami aneh sekali pernyataan Wensinck, sebab alQur'an berkali-kali menyuruh untuk mengerjakan shalat, begitu pula hadis Nabi saw yang menerangkan tentang shalat. A'zami menyatakan syahadat dibaca setiap tahiyat dalam shalat. Kemudian A'zami menggunakan metode sejarah sebagai bantahan dan pembatalan terhadap teori dan pernyataan pemikir orientalis tersebut.
\end{abstract}

\section{Keyword: Tiga Masjid, Dua Syahdat, Goldziher dan Wensinck}

\section{A. Latar Belakang Masalah}

Hadis atau Sunnah adalah teks normatif kedua (the second text) setelah alQur'an yang dijadikan pedoman hidup (Way of live) bagi umat Islam dan sebagai doktrin dalam ajaran Islam. Sejak zaman dulu umat Islam sepakat untuk menerima Hadis atau Sunnah dan menjadikannya sebagai sumber hukum Islam yang wajib dipatuhi. Perhatian umat Islam sangat besar terhadap hadis, sejak dahulu di masa Nabi saw, masa sahabat, ${ }^{1}$ tabiin dan tabiit tabiin. ${ }^{2}$

Kegiatan itu berjalan secara berkesinambungan, hingga mencapai puncaknya

${ }^{1}$ Pada periode ini, biasanya sistem periwayatan hadis melalui majlis al-ilmi, dan terkadang Nabi Muhammad dalam banyak hal juga meriwayatkan hadis melalui para sahabat tertentu yang kemudian para sahabat tersebut menyampaikanya kepada orang lain, serta melalui penyampaian ceramah dalam forum terbuka, seperti ketika fathul Makkah dan haji wada'.

2 Kajian hadis mencapai puncaknya ketika memasuki masa tadwin pada abad kedua hijriah yang dimotori oleh Umar bin Abdul Aziz. Dia merupakan pencetus kodifikasi hadis, sehingga hadis waktu itu menjadi topik kajian yang paling menarik, bahkan pasaca setelah tadwin muncul berbagai karya kitab yang sanagat monumental. Lutfi Maulana, "Periodesasi Perkembangan Studi Hadit: Dari Tradisi Lisan/Tulisan Hingga berbasis Digital”, (Jurnal Esensia, Vol 17, No. 1, April 2016), h. 112. 
pada era tabiit-tabiin. Hal ini menjadi logis karena para sahabat mengajarkan hadis jumlahnya sangat banyak dan masing-masing memiliki murid. Sangat wajar bila pemerhati hadis di masa tabiin jumlahnya makin meningkat dibanding pada masa sahabat. Jadi tidak logis jika sekarang ada yang menyatakan hadis Nabi saw itu tidak lebih dari dongeng-dongeng semata.

Al-Qur'an berbeda dengan al-Sunnah, baik dari segi lafaz, kemukjizatan, ta'abbud dan tilawahnya. Akan tetapi sunnah sama dengan al-Qur'an dari sisi kehujjahan dan dalilnya, bahwa sunnah sebagai penjelas terhadap al-Qur'an. Sunnah merupakan wahyu yang diturunkan kepada orang yang berbicara tidak berdasarkan hawa nafsunya. Sunnah adalah wahyu bi al-makna. ${ }^{3}$ Hal ini sebagaimana sabda Rasulullah saw : "Saya diberi wahyu dan yang semisal dengannya".

Hadis secara khusus berfungsi sebagai salah satu sumber dalam penetapan hukum, tentunya tidak sama dengan al-Qur'an, sebab al-Qur'an telah ditulis pada masa Nabi saw dan telah dibukukan pada masa pemerintahan Utsman bin Affan. Sedangkan Hadis baru dibukukan pada akhir abad pertama dan awal abad kedua hijrah yaitu pada masa pemerintahan Umar bin Abdul Aziz (61-101 H). ${ }^{4}$ Sehingga hadis tersebut menimbulkan sifat zanni al wurud yang memerlukan pengkajian yang intensif untuk mengetahui kualitas hadis tersebut, apakah shahih, hasan atau dhaif. ${ }^{5}$

Sekiranya hadis yang terhimpun dalam berbagai kitab hadis itu terdapat hadis yang lemah, ataupun palsu, tidaklah berarti bahwa seluruh hadis yang ada di dalamnya juga palsu atau lemah. Karena ulama telah melakukan pengkajian dan penelitian sangat cermat, kemudian memberikan persyaratan yang sangat ketat untuk diterimanya suatu hadis, yaitu sanad (transmisi) hadis harus bersambung, setiap perawi dari rangkaian atau sanad suatu hadis hurus bersifat adil, perawinya bersifat dabit, dalam hadis tidak terdapat zyāż dan tidak terdapat illat.

Apabila konsep periwayatan hadis tidak memenuhi kriteria lima syarat tersebut, maka kualitas hadis turun menjadi dhaif. Konsekuensinya hadis itu tidak bisa dijadikan sebagai argumentasi akidah, tidak bisa pula sebagai landasan hukum. Ia hanya bisa dijadikan sebagai dalil untuk memotivasi faḍāil al-a'māl menurut pendapat sebagian ulama hadis. ${ }^{6}$

\section{I, h. 15}

${ }^{3}$ Ahmad Ali bin Hajar al-Asqalani, Lisan al-Mizan, (Beirut: Dar al-Kutub al-Ilmiyyah, 1996), Juz

${ }^{4}$ Muhammad Ajjaj al-Khatib, Al-Sunnah Qabla al-Tadwīn, (Beirūt, Dārulfikr, 1981), h. 373.

${ }^{5}$ Hadis yang menimbulkan asumsi zanni adalah hadis ahad. Adapun hadis mutawatir sudah diyakini sebagai hadis Qațiy yang tidak perlu dikaji lagi.

6 Ibnu Hajar menjelaskan, hadis dhaif diamalkan dalam masalah faḍāil al-a'māl dengan tiga syarat; pertama, kelemahan hadisnya tidak terlalu parah (bukan hadis mudallas, mungkar dan matruk), kedua, hadisnya masuk pada katagori asal yang diamalkan, ketiga, ketika mengamalkan hadis lemah tidak meyakini sebagai ssebuah ketetapan yang paten, melainkan untuk kehati-hatian. Lihat Jalaluddin 
Pada masa lalu, sudah terdapat sejumlah orang atau kelompok yang menolak hadis, tetapi hal itu lenyap pada akhir abad ketiga Hijriah. Penolakan hadis ini muncul kembali pada abad ketiga belas Hijriah atau abad kesembilan belas Masehi yang dimotori oleh kesarjanaan Barat. Salah seorang sarjana Barat yang sangat mengguncangkan dunia Islam, dari hasil penelitiannya adalah Joseph Schacht, salah seorang murid Ignaz Goldziher, yang mengatakan bahwa sanad Hadis itu merupakan buatan para qadhi yang ingin melegitimasi pendapat mereka dengan menyandarkannya kepada tokoh-tokoh yang ada di belakang mereka dan akhirnya menyandarkan kepada Rasul.

Diskursus Hadis di Barat selalu merujuk kepada nama Ignaz Goldziher dan Joseph Schacht. Kedua tokoh tersebut telah wafat, tapi meninggalkan pengaruh global dan menciptakan mazhab skeptis di Barat. Disamping itu, juga ada orientalis bernama Wensinck yang menyatakan bahwa Hadis adalah buatan Sahabat.

A'zami secara khusus mengkritik dengan tuntas atas karya monumental Joseph Schacht, judulnya On Schacht's Origins of Muhammadan Jurisprudence dan karya Ignaz Goldziher, Introduction to Islamic Theology and Law, Setudes Sur La Tradition Islamique. A'zami dapat membuktikan dengan temuan naskah kuno Hadis abad pertama Hijriah dan analisis disertasi itu secara argumentatif menunjukkan bahwa Hadis betul-betul otentik dari Nabi saw .

Argumentasi yang dipaparkan oleh A'zami untuk mengkritik penginkar hadis, baik dari kalangan muslim maupun orientalis mejadi menarik untuk diteliti lebih lanjut. Alasannya, karena argumen A'zami dapat mematahkan teori orentalis yang menciptakan mazhab skeptis.

\section{B. Biografi Muhammad Mustafa al-A'zami}

Muhammad Mustafa al-A'zami lahir di kota Mano, India Utara, tahun 1932. Ayahnya pencinta ilmu dan membenci penjajahan, serta tidak suka bahasa Inggris. Watak ini mempengaruhi perjalanan studi A'zami, dimana ketika masih duduk di SLTA A'zami disuruh pindah oleh ayahnya ke sekolah Islam yang menggunakan bahasa Arab. Dari sinilah A'zami mulai belajar Hadis. Dia melanjutkan studinya di Collegge of Science di Deoband, sebuah perguruan tinggi terbesar di India, tamat tahun 1952. Kemudian dia melanjutkan studinya ke al-Azhar, Cairo di fakultas Bahasa Arab tamat tahun 1955. Kemudian dia kembali ke tanah Airnya. ${ }^{7}$

Abdirrahman bin Abi Bakar al-Suyuty, Tadrîb al-Rawî fî Syarah Taqrîb al-Nawawî, Juz I, (al-Madînah alMunawwarah: al-Maktabah al-Ilmiyyah, 1972), h. 198-199 2009), h. 700.

7 M. M. Azami, Hadis Nabawi dan Sejarah Kodifikasinya, ((Jakarta: Pustaka Firdaus 
Pada tahun 1956 dia diangkat sebagai dosen Bahasa Arab untuk orang-orang non Arab di Qatar. Tahun 1964 A'zami melanjutkan studinya lagi di Cambridge, Inggris dengan meraih gelar Ph.D. pada tahun 1966 dengan judul disertasi Studies in Early Hadis Literature. Lalu ia kembali lagi ke Qatar. Tahun 1968 dia pindah ke Makkah untuk mengajar di Fakultas Pasca Sarjana, Jurusan Syari'ah dan Studi Islam, Universitas King Abdul aziz (kini Universitas Ummul Qura), dan beliau pernah menjabat sebagai kepala jurusan Studi Keislaman. Tahun 1980 dia mendapatkan hadiah Internasional Raja Faisal untuk studi Islam dari lembaga Hadiah Yayasan Raja Faisal di Riyadh. ${ }^{8}$ Dia sebagai Profesor Tamu Yayasan Raja Faisal di bidang Studi Islam pada Universitas Princeton, Cendekiawan Tamu pada Universitas Colorado (Boulder). Dia juga sebagai Professor kehormatan pada Universitas Wales (Lampeter). ${ }^{9}$

Karya-karyanya antara lain: Studies in Early Hadith Literature, Hadith Methodology dan Literaturnya, On Schacht's Origin of Muhammadan Jurisprudence, Dirasat fi al-Hadith an-Nabawi, Kuttab anNabi, Manhaj al-Naqd 'ind al-Ilal Muhaddithin, dan al-Muhaddithin min alYamamah, The Qur'anic Challenge: A Promise Fulfilled (Tantangan AI-Qur'an: Suatu Janji yang Telah Terpenuhi), dan The Isnad System : Its Origins and Authenticity (Sistem Isnad: Keaslian dan Kesahihannya). Beberapa buku yang dieditnya antara lain: al-`Ilah of lbn al-Madini, Kitab at-Tamyiz of Imam Muslim, Maghazi Rasulullah of 'Urwah bin Zubayr, Muwatta Imam Malik, Sahih Ibn Khuzaimah, dan Sunan Ibn Majah. Beberapa karya al-A'zami telah diterjemahkan ke dalam beberapa bahasa lain.

Muhammad Mustafa A'zami dapat dikatakan sebagai sarjana muslim yang ulung di era moderen ini dan menguasai disiplin ilmu: ilmu al-Qur'an, ilmu Hadis, Hadis, ushul al-din, perbandingan kitab suci dan sejarah. Karya yang paling monumental Dirasat fi al-Hadith an-Nabawi wa tarikh tadwinih dari hasil desertasinya, telah mendapat apresiasi. Diantaranya adalah:

1. A.J. Arberry pada tahun 1967 berkomentar:

Dalam hal ini, A'zami telah melakukan pekerjaan yang unggul dan sangat berharga, serta hal itu dilakukan berdasarkan standar-standar yang benar menurut penelitian ilmiah. Dan disertasi yang ia ajukan, dimana ia dianugrahi gelar doktor dalam filsafat oleh Universitas Cambridge, menurut pendapat saya adalah termasuk penelitian ilmiah yang paling mengagumkan dan paling asli, yang dilakukan dalam bidang itu pada masa sekarang. ${ }^{10}$

8 Ibid, h. 700.

9 M. Musthofa Al-A'zami, The Histoy of The Qur'anic Text, Penerjemah Sohirin solihin dkk, (Jakarta: Gema Insani Press, 2005), h.

10 M.M. Azami, Dirasāt fí al-Hadīs al-Nabawī wa Tārīkh wa Tadwīnih, (Beirut: al-Maktabah alIslami, 1992), h. vii 
2. Karya yang paling monumental Dirasaât fî al-Hadîts al-Nabawî wa Târîkh wa Tadwînih, telah mendapatkan hadiah internasional Raja Faisal untuk studi Islam tahun 1400 H/1980 M. Sebagai penghargaan atas karyanya dalam bidang kajian yang berkaitan dengan Hadis nabawi, yang tercermin dalam hal sebagai berikut:

Bahwa kitabnya yang berjudul Dirasaāt fí al-Hadīs al-Nabawî wa Tārīkh wa Tadwīnih merupakan karya akademis yang bagus, yang membuktikan adanya usaha ilmiah yang terpuji dan menunjukkan suatu loyalitas yang jujur kepada Hadis nabawi, seraya mengikuti metode ilmiah, menagkis kepalsuankepalsuan mereka dan mengkritik pendapat-pendapat mereka dengan argumen yang kuat, serta meruntuhkan sumber-sumber rujukan yang lemah yang dijadikan pegangan oleh mereka, menyingkap kekeliruan mereka dalam memahami sebuah sumber rujukan dalam bahasa Arab. Dengan demikian kitabnya itu menempati posisi paling depan besama kajian-kajian yang baik pada masa kini dalam bidang Hadis, serta memberikan andil yang cukup dalam berhidmat kepada Hadis Nabi saw dari segi sejarah, pembukuan dan penysunannnya, begitu pula dalam hal menyanggah kepalsuan orang-orang yang ingin menodai Hadis. ${ }^{11}$

3. Ali Mustafa Yaqub, murid A'zami yang mendapatkan mandat darinya untuk mempublikasikan karyanya dengan bahasa Indonesia mengatakan:

A'zami adalah pakar muslim yang pertama kali melakukan penghancuran besar-besaran terhadap teori-teori orientalis dalam kajian Hadis, A'zami adalah sosok cendikiawan muslim yang ideal, karena meskipun dia belajar dibawah asuhan tokoh-tokoh orientalis Barat, namun beliau tidak menjadi torompet yang meneriakkan pikiran-pikiran orientalis dikalangan masyarakat muslim. Justeru sebaliknya, beliau ibarat bumerang yang menghantam kembali posisi mereka. ${ }^{12}$

\section{Pengertian Hadis}

Hadis secara etimologi berarti baru (jadìd). Adapun pengertian Hadis menurut secara terminologi menurut ulama hadis, usul fikih dan ulama fikih terdapat perbedaan, namun esensinya masih sama. Menurut ahli hadis, hadis adalah ucapan, pekerjaan, ketetapan, sifat (watak budi dan jasmani), dan tingkah laku Nabi saw Muhammad, baik sebelum menjadi Nabi saw maupun sesudahnya. Disini menunjukkan bahwa Sunnah sinonim dengan Hadis menurut sebagian mereka. ${ }^{13}$ Asumsinya adalah apa pun yang berasal dari Nabi saw merupakan petunjuk atas cara Nabi saw dalam memahami dan mengamalkan Islam. ${ }^{14}$ Ada juga yang

\footnotetext{
11 Ibid, h.v.

12 Ali Mustafa Yaqub, Kritik Hadis, (Jakarta: Pustaka Firdaus, 2000), h. 26.

13 Musthafa al-Siba'i, al-Sunnah wa Makānatuhā fi tasyri' al-Islamī. (al-Maktabah al-Islamî, 2000), h.65.

14 Yusuf al-Qardhawi, Pengantar Studi Islam, Penerjemah Agus Suyadi Raharusun dan Dede Rodin, (Bandung: CV Pustaka Setia, 2007), h. 18.
} 
mendefinisikan:

$$
\text { كل ما أضيف إلى النبي صلي الله عليه وسلم قولا أو فعلا أو تقريرا أو صفة }
$$

"Segala sesuatu yang disandarkan kepada Nabi saw berupa ucapan, perbuatan, ketetapan dan sifat (watak budi dan jasmani, gerakan dan diamnya ketika bangun dan tidur $) .15$

A'zami menjelaskan, arti Sunnah Atau hadis tersebut telah disepakati oleh para ulama, baik dari kalangan bahasa, usul fikih, fikih maupun Hadis. ${ }^{16}$ Akan tetapi ulama fikih dan ushul tidak memasukkan sifat Nabi saw sebagai hadis.

\section{Sistem Periwayatan Hadis}

Hadis Nabi saw Muhammad yang terhimpun dalam kitab-kitab hadis melalui proses periwayatan. Dalam periwayatan hadis harus memenuhi tiga unsur, yakni: (1) kegiatan menerima hadis dari periwayat hadis (at-tahammul); (2) kegiatan menyampaikan hadis kepada orang lain ( $\left.a l-a d \bar{a}^{\prime}\right)$; dan (3) penyebutan susunan rangkaian periwayatannya ketika menyampaikan hadis (al-isnād). ${ }^{17}$

1. Syarat-syarat Serah Terima Hadis

Mahmud Tahhan Menjelaskan, menurut pendapat yang paling sahih tidak ada persyaratan Islam dan balig dalam penerimaan hadis (at-tahammul al-hadīs), namun dalam menyampaikan hadis (al-adā') disyaratkan Islam dan balig bagi periwayat. Berdasarkan hal tersebut, maka periwayatan oleh orang muslim balig tentang hadis yang diterimanya ketika ia belum masuk Islam akan diterima (maqbūl), hanya saja dalam kasus seperti ini tamyīz tetap dipersyaratkan bagi yang belum balig. ${ }^{18}$

2. Bentuk-bentuk Periwayatan Hadis

Dalam proses periwayatan hadis terdapat beberapa bentuk atau model. Bentuk periwayatan di sini mencakup pada al-tahammul (pengambilan riwayat) dan $a l-a d \bar{a}^{\prime}$ (penyampaian riwayat). Adapun bentuk-bentuk periwayatannya sebagai berikut; Mendengar (as-simā'). Dalam proses periwayatan hadis mendengar merupakan bentuk (sigat) tertinggi dan paling kuat dibandingkan dengan bentuk-

15 Abdurrahman as-Sakhawi, Fathul Mghiș Bisyarah Alfiyyatil Hadiș. Lihat pula, Al-Qadi zainuddin Abi Yahya Zakariyya bin Muhammad, Fath al-Bāqī bi Syarah Alfiyah al-'Raqī, Juz I, (Beirut; Barul Kutub Ilmiyah 1422/2002), h. 95. Lihat pula At-Tirmisi, Manhaj Dhawi al-Nazar, (Beirut : Dar alFikr, 1974), 8

16 M.M. Azami, Dirāsāt fî al-Hadīs al-Nabawī wa Tārīkh wa Tadwīnih, h. 2.

17 Muhammad Ujjad al-Khatib, Ushul al-Hadīs Ulumuhu wa Musthaluhu, (Beirut: Libanun. 1989), h. 227.

18 Mahmud Tahhan, Taisir Musthalah al-Hadis, (tp, th), h. 131-132. 
bentuk periwayatan yang lainnya; ${ }^{19}$ Membacakan (al-qirāah). Sistem periwayatan dengan membaca adalah seorang murid membacakan kepada gurunya, baik secara hafalan maupun tulisan. Sementara guru mendengarkannya; Ijāzah, ijāzah adalah memberikan izin periwayatan baik secara ucapan maupun tulisan. Bentuk ijāzah ini seperti halnya ucapan seorang guru kepada murid : "saya memberikan ijazah kepadamu untuk meriwayatkan kitab Șahih al-Bukhārī”;20Al-Munāwalah, Almunāwalah ialah seorang guru memberi sebuah atau beberapa hadis atau kitab untuk diriwayatkan. Metode ini mirip ijazah, karena ada ungkapan eksplisit dari guru bahwa murid diberi ijazah boleh meriwayatkan hadis yang diberikan. Pemberian ini ada kalanya disertai bemberian izin untuk diriwayatkan dan ada kalanya tidak disertai izin. Cara yang pertama disepakati oleh ulama penggunaannya, sementara yang kedua tidak diperbolehkan; ${ }^{21}$ Mukātabah Sistem periwayatan mukātabah adalah seorang guru menulis sendiri atau dia memerintahkan orang lain menulis riwayatnya kepada orang yang hadir di tempatnya atau yang tidak hadir di situ. Periwayatan dengan cara mukātabah ada dua, disertai dengan izin dan tidak; Al-I'lām. Periwayatan dengan al-i'lām adalah Guru memberi tahu kepada perawi atau murid bahwa hadis ini atau kitab ini termasuk riwayat darinya atau dari yang didengarnya dari seorang (fulan) tanpa memberi ijazah untuk menyampaikannya. Mayoritas ulama membolehkan meriwayatkan bentuk seperti ini dan dijadikan salah satu bentuk penanggungan hadis (at-tahammul); Al-Wasiyah. Wasiyah adalah seorang syekh mewasiatkan diwaktu naza' atau dalam safar sebuah kitab yang ia wasiatkan kepada seorang rawi, yakni berwasiat kepada seseorang tentang kitab tertentu yang diriwayatkan ${ }^{22}$; Al-Wijädah. Seorang periwayat (rawi) mendapatkan hadis atau kitab dengan tulisan orang yang meriwayatkannya, sedangkan hadis-hadis ini tidak pernah si perawi mendengar atau menerima dari guru yang menulisnya.

\section{E. Kedudukan Hadis}

Sebagai teks normatif kedua, hadis merupakan pedoman hidup (way of live) bagi umat Islam dan sebagai doktrin dalam ajaran Islam. Sejak zaman dulu umat Islam sepakat untuk menerima hadis dan menjadikannya sebagai sumber hukum Islam yang wajib dipatuhi. Karena dengan adanya hadis ajaran Islam menjadi jelas, rinci, spesifik dan aplikatif.

${ }^{19}$ Ibid, h. 133.

20 Ibid, h. 134

${ }^{21}$ Hedhri Nadhiran, Periwayatan Hadis Bil Makna Implikasi dan Penerapannya Sebagai 'Uji' Kritik Matan Di Era Modern, Jurnal JIA/Desember 2013/Th.XIV/Nomor 2/187-207, h. 192

22Mahmud Tahhan, Taisir Musthalah al-Hadis, h. 135 
Ketetapan hadis sebagai sumber hukum kedua dalam ajaran Islam berdasarkan pada Firman Allah Ta'ala Qs. Al-Hasyr [59]: 7 yang berbunyi:

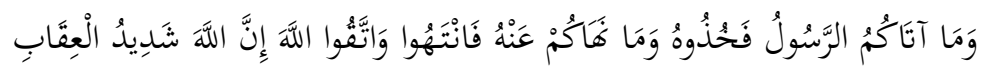

“Dan apa saja yang datang dari Rasulullah shallallahu 'alaihi wa sallam kepada kalian, maka ambillah (laksanakanlah), dan apa saja yang kalian di larang untuk mengerjakannya, maka berhentilah (tinggalkanlah Sesungguhnya Allah amat keras hukumannya. (QS. al-Hasyr: 7)

Juga dalam surat an-Nisa' ayat 80 juga dikemukakan :

$$
\text { مَنْ يُطِع الرَّسُولَ فَتَدْ أَطَعَ اللَّهُ }
$$

Barang siapa yang mengikuti Rasul maka sesunguhnya ia telah mentaati Allah.

Ayat tersebut mengandung petunjuk bahwa kepatuhan kepada Rasulullah saw merupakan salah satu tolok ukur kepatuhan seseorang kepada Allah swt. Ayat tersebut juga sebagai informasi bahwa perkara yang diputuskan oleh Rasulullah saw menjadi sebuah aturan yang mengikat dan sesuatu yang dicontohkan olehnya menjadi teladan bagi umat Islam.

Oleh karena itu, Allah menganjurkan kepada kita agar beliau dijadikan sebagai idola dan teladan dalam semua aspek kehidupan ini. Hal ini tertuang dalam QS. Al-Ahzab [33]: 21.

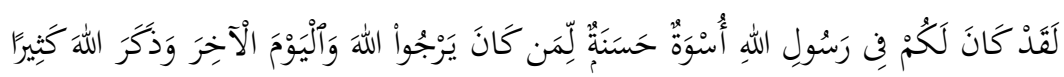

"Sesungguhnya Telah ada pada (diri) Rasulullah itu suri teladan yang baik bagimu (yaitu) bagi orang yang mengharap (rahmat) Allah dan (kedatangan) hari kiamat dan dia banyak menyebut Allah".

Keteladanan tersebut dapat diikuti oleh setiap manusia, karena beliau telah memiliki sifat-sifat yang agung dan terpuji. Beliau mendapat bimbingan dari Allah dan kedudukan yang istimewa di sisi-Nya. Mereka yang sempat bertemu langsung dengan beliau maka cara meneladaninya langsung dari beliau, bagi mereka yang tidak bertemu dengan beliau maka cara meneladaninya dengan mempelajari, memahami dan mengikuti petunjuk berdasarkan hadis-hadisnya.

\section{F. Pandangan Goldziher terhadap Hadis Pergi ke-tiga Masjid}


Ignaz Goldziher menyatakan, ${ }^{23}$ bahwa penelitian hadis yang dilakukan oleh ulama klasik tidak dapat dipertanggungjawabkan secara ilmiah karena kelemahan metodenya. Hal itu dikarenakan para ulama lebih banyak menggunakan metode kritik sanad, dan kurang menggunakan metode kritik matan. Karenanya, Goldziher kemudian menawarkan metode kritik baru yaitu kritik matan saja. ${ }^{24}$ Sebenarnya para ulama klasik sudah menggunakan metode kritik matan. Hanya saja apa yang dimaksud metode kritik matan oleh Goldziher itu berbeda dengan metod kritik matan yang dipakai oleh para ulama. Menurutnya, kritik matan Hadis itu mencakup berbagai aspek, seperti politik, sains, sosio kultural dan lain-lain. Ia mencontohkan Hadis-Hadis yang terdapat dalam kitab shahih Bukhari, dimana menurutnya, Bukhari hanya melakukan kritik sanad dan tidak melakukan kritik matan. Sehingga tidak menutup kemungkinan dalam kitab shahih Bukhari tersebut terdapat Hadis-Hadis palsu. Contohnya hadis tidak diperintahkan bepergian kecuali menuju ketiga Masjid, riwayat dari Abu Hurairah:

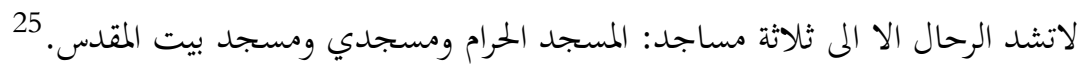

“Janganlah kalian bepergian, kecuali menuju ketiga Masjid: Masjid al-Haram, Masjid Nabawi dan Masjid al-Aqsha."

Menurut Goldziher hadis ini palsu karena buatan Ibnu Shihab al-Zuhri bukan ucapan Nabi saw sekalipun terdapat dalam kitab shahih Bukhari. Ibnu Shihab alZuhri menurut Goldziher dipaksa oleh Abdul Malik bin Marwan penguasa dinasti Umayyah waktu itu untuk membuat hadis tersebut karena khawatir Abdullah bin Zubair (yang memproklamirkan dirinya sebagai khalifah di Makkah) menyuruh warga Syam yang sedang beribadah haji untuk berbaiat kepadanya. Karenanya, Abdul Malik bin Marwan berusaha agar warga Syam tidak lagi pergi ke Makkah, tetapi cukup hanya pergi ke Masjid al-Aqsha yang pada saat itu menjadi wilayah Syam. ${ }^{26}$

${ }^{23}$ Ignaz Goldziher adalah orientalis Hungaria yang dilahirkan dari keluarga Yahudi pada tahun 1850 Masehi. Ia belajar di Budapest, Berlin dan Leipzig. Ignaz Goldziher merupakan anak yang selalu ingin tahu, keinginannya untuk memperdalam keilmuannya sangat kuat. Banyak guru-guru yang memuji kepiawaiannya dalam mendefinisikan suatu permasalahan. Pendidikannya dimulai dari Budhaphes, kemudian melanjutkan ke Berlin dan Liepziq pada tahun1869. Lihat Achmad Zuhdi DH, Pandangan Orientalis Barat tentang Islam Antara yang Menghujat dan yang Memuji, (Surabaya: Karya Pembina Swajaya, 2004), h. 142.

24 Dalam bukunya "Muhammedanische Studien", terdiri dari 2 jilid. Dia menyatakan bahwa, sebagian besar hadis tidak dapat dijamin keasliannya alias palsu. Karena itu hadis tidak dapat dijadikan sebagai sumber informasi mengenai sejarah awal Islam. Hadis lebih merupakan refleksi interaksi dan konflik pelbagai aliran dan kecenderungan yang muncul di kalangan masyarakat muslim pada periode kematangannya, ketimbang sebagai dokumen sejarah awal perkembangan Islam. Menurutnya lagi, hadis adalah produk bikinan masyarakat Islam beberapa abad setelah wafatnya nabi Muhammad . Lihat Syamsuddin Arif, Gugatan Orientalis Terhadap Hadis dan Gaungnya di Dunia Islam, dalam Al-Insan Jurnal Kajian Islam, No. 2, Vol. 1, 2005, h. 11

25 Al-Bukhari, no.1189.

${ }^{26}$ A'zami, Juz II, hm. 457. Liahat pula M.M. Azami, Manhaj al-Naqdi 'Ind al-Muhadditsîn, ( Su'udi 


\section{G. Pandangan Wensinck Tentang Hadis Akidah}

A.J. Wensinck ${ }^{27}$ mengungkapkan, beberapa dekade sesudah Nabi saw wafat, terjadi perkembangan dalam pemikiran dan pekerjaan. Perkembangan ini menginspirasi tokoh-tokoh spiritual untuk menjelaskan tentang semangat Islam yang terdapat dalam hadis-hadis Nabi saw. diantaranya adalah hadis tentang akidah (dua syahadah) dan hadis tentang Islam yang ditegakkan atas lima pilar. ${ }^{28}$ Buktinya menurut Wensinck hadis itu dibuat oleh para sahabat. Sebab Nabi saw tidak pernah mempuanyai suatu ungkapan khusus yang pasti diucapkan oleh orang-orang yang baru masuk Islam. Menurutnya ketika orang-orang Islam bertemu dengan orangorang Kristen di Syam, mereka mengetahui bahwa orang-orang kristen mempunyai ungkapan khusus. Maka mereka perlu memilki ungkapan khusus yang membangkitkan semangat Islam dalam bentuk hadis akidah dan hadis lima pilar tentang Islam. ${ }^{29}$

\section{H. Kritik A'zami Terhadap Goldziher dan Wensinck}

Adapun kritik A'zami terhadap Goldziher mengenai kritiknya di atas, A'zami menyatakan, tidak ada bukti historis yang mendukung teori Goldziher. Para sjarahwan berbeda pendapat tentang kelahiran al-Zuhri, antara 50 sampai 58 H. ${ }^{30} \mathrm{Al}$ Zuhri juga belum pernah bertemu dengan Abdul Malik bin Marwan sebelum tahun 81 H. Pada tahun 68 H orang-orang dari Dinasti Umayyah berada di Makkah pada musim haji.

Apabila demikian adanya, al-Zuhri pada saat itu masih berumur 10 sampai 18 tahun. ${ }^{31}$ Karenanya sangat tidak logis seorang anak yang baru berumur belasan tahun sudah populer sebagai intelektual dan memiliki reputasi ilmiah di luar daerahnya sendiri, dimana ia mampu mengubah pelaksanaan ibadah haji dari Makkah ke

Arabiyyah: Maktabah al-Kautsar, 1990), h. 127-128.

27 Nama lengkapnya adalah Aren Jan Wensinck lahir pada 7 Agustus 1882 di Aarlanderveen, Belanda bagian selatan. Ia lahir dan tumbuh dalam lingkungan keluarga Kristen Protestan yang taat. Ayahnya seorang pendeta membrkan banyak pengaruh terhadap kepribadian Wensinck, sehingga ia berkeinginan menjadi seorang pendeta, sebagimana bapaknya. Karena itu, setelah lulus dari Gymnasium 3 di kota Amersfootrt, ia mendaftarkan diri sebagai mahasiswa teologi di Uneversitas Utrech pada 19014. Tetapi setahun kemudian dia merubah minatnya dari teologi ke studi bahasa-bahasa semet pada fakutas sastra di Univesitas yang sama dibawah bimbingan M.T. houtsma (1850-1945)

${ }^{28}$ A'zami, hm. 460.

${ }^{29} \mathrm{Ibid}, \mathrm{hm} .460$.

30 Nama lengkapnya adalah Abu Bakar Muhammad ibn Muslim ibn' Ubaidillah ibn Syihab ibn Abdullah ibn al-Harits ibn Zuhrah ibn Kilab ibn Murrah al-Qurasyi al-Zuhri al-Madani, beliau lahir pada tahun $50 \mathrm{H}$, menurut pendapat yang paling kuat, yaitu pada masa pemerintahan khalifah mu'awiyah ibn Abi Sufyan. Al-Zuhri hidup pada akhir masa sahabat, dan dia masih bertemu dengan sejumlah sahabat ketika dia berusia 20 tahun lebih. Oleh karenanya, dia mendengar hadits dari para sahabat seperti Anas ibn Malik. Abdullah ibn Umar, Jabir ibn Abdillah, Sahal ibn Sa'ad, Abu al-Thufail, al-Masur ibn Makhramah dan lainnya. Lihat Musthafa al-Siba'i, al-Sunnah wa Makanatuha fi tasyri' al-Islami. (al-Maktabah alIslami, 2000), h. 232.

31 A'zami, Dirasaât fí al-Hadîts al-Nabawî, h. 457. 
Jerusalem. Lagi pula di Syam pada saat itu masih banyak para sahabat dan tabi'in yang tidak mungkin diam saja melihat kejadian itu. ${ }^{32}$ Bila demikian, berarti al-Zuhri pada saat itu baru berumur antara 10-18 tahun. Dan sangat tidak logis, anak seusia itu sudah popular sebagai seorang intelektual di luar daerahnya sendiri, dimana ia mampu mengubah pelaksanaan ibadah haji dari Makkah ke Yerussalem. Lagi pula, pada saat itu, di Syam masih banyak sahabat dan para tabi'in yang tidak akan tinggal diam melihat fenomena itu. ${ }^{33}$ Selain itu, dalam hadis di atas, sama sekali tidak ada indikasi yang menyatakan bahwa ibadah haji dapat dilakukan di al-Quds. Yang ada hanyalah pemberian isyarat keistimewaan kepada masjid al-Aqsha. Dan hal itu wajar saja, mengingat ia pernah menjadi Kiblat pertama bagi kaum muslimin. Disisi lain tampaknya Goldzihe hanya menuduh al-Zuhri saja yang memalsu hadis ini. Padahal, tidak kurang 18 orang meriwayatkan hadis tersebut, selain al-Zuhri. Atas dasar ini, Goldziher telah melakukan kecerobohan yang mendasar. ${ }^{34}$

Sementara teks hadisnya sendiri tidak menunjukkan bahwa ibadah haji dapat dilakukan di Jerusalem. Yang ada hanyalah isyarat pengistimewaan kepada Masjidil Aqsha yang pernah dijadikan kiblat umat Islam. Dari sini nampaknya tidak terlalu sulit bahwa tujuan utama Goldziher adalah untuk meruntuhkan kredibilitas Imam Bukhari. Apabila umat Islam sudah tidak percaya lagi kepada shahih Bukhari, maka hadis-hadis Rasulullah di dalamnya tidak akan dipakai lagi. Pada gilirannya kemudian imam-imam ahli hadis lainnya juga dikorbankan. Tetapi sanggahan dan kritik A'zami terhadap Goldziher ini sudah sangat memuaskan, karena dia menunjukkan bukti-bukti perawi hadis di atas, selain al-Zuhri, terdapat 18 perawi sebagaimana dia cantumkan dalam bukunya. ${ }^{35}$

Adapun kritkt A'zami terhadap Wensinck, dia menyatakan, sebenarnya dia tahu bahwa dua syahadat itu merupakan bagian dari tasyahhud dibaca setiapa tahiyat dalam shalat. Wensinck justru menuduh bahwa shalat itu baru selesai dalam bentuknya yang terakhir sesudah Nabi saw wafat. Menurut A'zami Aneh sekali. Sebab al-Qur'an berkali-kali menyuruh untuk mengerjakan shalat, begitu pula hadis Nabi saw yang menerangkan tentang shalat banyak. Beliau telah mengajarkan shalat pada sahabat dalam bentuk yang sempurna. Shalat juga dilaksanakan secara berjamaah. Pada tahun pertama dan kedua Hijriah sudah ada azan, di mana salah satu isinya terdapat dua kalimat syahadat. Kalau demikian halnya, maka kata A'zami penelitian

32 Ibid, hm. 458.

33 Ibid, hm. 458

34 Ibid, hm. 458.

35 A'zami mengklasifikasikan, bahwa semua perawi hadis (tentang keutamaan tiga Masjid) terdiri dari 19. Urutan yang terakhir adalah al-Zuhri yang meriwayatkan hadis dari Said, dari Abu Hurairah. Pembahasan lebih lanjut bisa dilihap pada halaman 459-460. 
Wensinck adalah omong kosong belaka. ${ }^{36}$

\section{Pembuktian Sejarah}

Untuk membantah teori yang dikemukakan oleh para orientalis di atas, maka A'zami mengkritik melalui pendekatan dan penelitian sejarah, khususnya sejarah Hadis. ${ }^{37}$ A'zami melakukan penelitian khusus tentang hadis-hadis Nabi saw yang terdapat dalam naskah-naskah klasik. Di antaranya adalah naskah milik Suhail bin Abi Shaleh (w.138 H). Abu Shaleh (ayah Suhail) adalah murid Abu Hurairah sahabat Nabi . Naskah suhail ini berisi 49 Hadis. Sementara A'zami meneliti perawi hadis itu sampai kepada generasi Suhail, yaitu jenjang ketiga (al-thabaqah altsalitsah). Termasuk jumlah dan domisili mereka. A'zami membuktikan bahwa pada jenjang ketiga, jumlah perawi berkisar 20 sampai 30 orang, sementara domisili mereka terpencar-pencar dan berjauhan, antara India sampai Maroko, antara Turki sampai Yaman. Sementara teks hadis yang mereka riwayatkan redaksinya sama. ${ }^{38}$

A'zami berkesimpulan bahwa sangat mustahil menurut ukuran situasi dan kondisi pada saat itu mereka pernah berkumpul untuk membuat hadis palsu sehingga redaksinya sama. Dan sangat mustahil pula bila mereka masing-masing membuat hadis, kemudian oleh generasi berikutnya diketahui bahwa redaksi hadis yang mereka buat itu sama. Kesimpulan dari pendapat A'zami ini menolak kesimpulan orientalis, baik tentang rekontruksi terbentuknya sanad hadis, maupun bunyi teks (matan) Hadis tersebut. Sebagai contoh, A'zami mengemukakan Hadis yang artinya di mana Nabi saw . bersabda : "Apabila salah seorang di antara kamu bangun dari tidurnya, maka hendaknya ia mencuci tangannya, karena ia tidak tahu semalam tangannya berada di mana ". Hadis ini dalam naskah Suhail bin Abi Shaleh berada pada urutan nomor 7, dan pada jenjang pertama (generasi sahabat) diriwayatkan oleh lima orang, yaitu Abu Hurairah, Ibn Umar, Jabir, Aisyah, dan Ali bin Abi Thalib. Abu Hurairah sendiri kemudian meriwayatkan hadis tersebut kepada 13 orang tabi'in (generasi kedua). 13 orang tabi'in ini kemudian menyebar ke berbagai penjuru negeri Islam. 8 orang tetap tinggal di Madinah, seorang tinggal di Kufah, 2 orang tinggal di Basharah, seorang tinggal di Yaman, dan seorang lagi tinggal di Syam. Tiga belas

36Ibid, hm. 461.

37 Kajian degan objek peristiwa yang terjadi di masa lalu harus menggunakan pendekatan sejarah. Sejarah sebagai pisau analisis dalam mengkaji Islam (al-Qur'an dan Hadis). Biografi Nabi yang paling awal dan otoritatif disusun dari literatur Hadis yang terkumpul pada abad kedua setelah kematian Nabi . oleh Ibn Ishak dan diedit oleh Ibn Hisyam. Lihat Jamali Sahrodi, Metodologi Studi Islam, (Bandung: CV Pustaka Setia, 2008), h. 123.

${ }_{38}$ A'zami, Studies in Early Hadits Literature, (Indianapolis-Indiana, American Trust Publication, 1978), h. 222-223. 
Tabi'in ini kemudian meriwayatkan lagi kepada generasi berikutnya (generasi ketiga, Tabi' Tabi'in), dan jumlah mereka menjadi tidak kurang dari 16 orang. Mereka tinggal di Madinah 6 orang, Bashrah 4 orang, Kufah 2 orang, Makkah 1 orang, Yaman 1 orang, Khurasan 1 orang, dan Himsh-Syam 1 orang. ${ }^{39}$ Maka mustahil 15 orang yang domisilinya terpencar-pencar di tujuh kota yang berjauhan itu pernah berkumpul pada satu saat untuk bersama-sama membuat Hadis palsu yang redaksinya sama, atau mustahil pula, bila mereka secara sendiri-sendiri di kediamannya masingmasing membuat Hadis, dan kemudian diketahui bahwa redaksi Hadis tersebut secara kebetulan sama. 16 orang rawi di atas adalah hanya dari jalur Abu Hurairah. Apabila jumlah perawi itu ditambah dengan peraw dari empat jalur lainnya, yaitu Ibn Umar, Jubir, Aisyah, dan Ali, maka jumlah perawi itu akan menjadi lebih banyak. ${ }^{40}$

Dengan demikian apa yang dikembangkan oleh Goldzeher dan Wensinck yang mengemukakan bahwa sanad hadis itu baru terbentuk belakangan dan merupakan buatan para sahabat menurut pandangan Goldzeher dan Wensinck adalah tidak benar. Hal ini sudah dibuktikan oleh A'zami dengan penelitiannya bahwa sanad hadis itu memang muttashil sampai kepada Rasulullah . melalui jalur-jalur yang telah disebutkan di atas. Hal ini membuktikan juga bahwa hadis-hadis yang berkembang sekarang merupakan perbuatan atau ucapan yang datang dari Rasulullah .

Menurut hemat peneliti kalau ditelusuri lebih jauh, para orientalis (Goldzeher dan Wensinck) dalam mengkaji teks hadis cenderung berdasarkan pada perspektif Barat,"11 dan dipengaruhi oleh teori Bibel. Maurice Bucaille menyatakan, "Sebelum tersusun menjadi kumpulan pasal-pasal, Perjanjian Lama merupakan tradisi rakyat yang tidak mempunyai sandaran, kecuali dalam ingatan manusia, satusatunya faktor untuk tersiarnya ide, tradisi-tradisi tersebut selalu dinyanyikan". 42 Edmond Jacob kemudian menyimpulkan, "Adalah sangat mungkin bahwa apa yang dikisahkan oleh Perjanjian Lama tentang Nabi Musa dan tokoh agama Yahudi tidak sesuai dengan yang terjadi dalam sejarah, akan tetapi para tukang dongeng dalam masa riwayat secara lisan sudah dapat mengisikan keindahan dan imaginasi untuk merangkai episode yang bermacam-macam".43

${ }^{39}$ Ibid, h. 225-226.

40 Ibid, h. 227.

41Para pendahulu orientalis mengkaji Islam dengan perspektif Barat yang bias dalam melihat objek. Kecenderungan orientalis klonial lebih suka menjustifikasi objek (masyarakat Muslim) dengan dasar pemahaman mereka terhadap teks agama yang dalam tataran aplikasinya bias dan kurang menyentuh akar pemahaman masyarakat Islam itu sendiri. Lihat Jamali Sahrodi, Metodologi Studi Islam, (Bandung: CV Pustaka Setia, 2008), h. 146.

${ }_{42}$ Maurice Bucaille, ter. H.M. Rasyidi,Bibel, Qur-an, dan Sains Modern. Judul Asli: La Bible Le Coran Et La Science, (Penerbit Bulan Bintang, 1979), h. 5.

43Ibid, h. 6. 
Secara umum, teori orientalis banyak dipengaruhi oleh teori Bibel dalam mengkaji teks tradisi (turats) Islam. Hal ini dapat diketahui oleh pernyataan Josef Horovitz yang berspekulasi bahwa besar kemungkinan praktek isnād berasal dari dan dipengaruhi oleh tradisi oral sebagaimana dikenal dalam literatur Yahudi. ${ }^{44}$

Peneliti sepakat dengan pendapat A'zami bahwa sangat mustahil menurut ukuran situasi dan kondisi pada saat itu mereka (kamun muslimin yang meriwayatkan hadis) berkumpul untuk membuat hadis palsu sehingga redaksinya sama. Karena diantara syarat diterimanya hadis harus diriwayatkan secara tersambung mulai dari sahabat sampai ke mukharrij hadis. Begitu pula masingmasing periwayat hadis harus adil, bukan perawi fasik dan perawi bohong. Dengan demikian, tuduhan Goldzeher dan Wensinck terhadap sahabat dan generasi setelahnya yang dianggap membuat hadis sendiri (hadis bukan datang dari Nabi) adalah tuduhan yang tidak berdasarkan pada fakta yang benar. Dengan kata lain, tuduhan Goldzeher dan Wensinck adalah tuduhan bohong.

\section{J. Kesimpulan}

A'zami telah melakukan kritikan yang tajam terhadap pernyataan oerientalis yang menuduh hadis tidak otentik. Diantara orientalis yang dikritik:

Goldziher menyatakan penelitian hadis yang dilakukan oleh ulama tidak dapat dipertanggungjawabkan secara ilmiah karena kelemahan metodenya. Karena ulama lebih banyak menggunakan metode kritik sanad, dan kurang menggunakan metode kritik matan. Dia menuduh Hadis tentang perintah berziarah pada tiga masjid buatan Ibnu Shihab Az-Zuhri. Az-Zuhri menurut Goldziher dipaksa oleh Abdul Malik bin Marwan untuk membuat Hadis.

Menurut A'zami, tidak ada bukti historis yang mendukung teori Goldziher. Para sjarahwan pendapat tentang kelahiran al-Zuhri, antara 50 sampai $58 \mathrm{H}$. Al-Zuhri Apabila demikian adanya, al-Zuhri pada saat itu masih berumur 10 sampai 18 tahun. Karenanya sangat tidak logis seorang anak yang baru berumur belasan tahun sudah populer sebagai intelektual dan memiliki reputasi ilmiah di luar daerahnya sendiri

Dia mengingkari tentang Hadis akidah. Menurutnya Hadis tentang akidah (dua syahadah) dan Hadis tentang Islam yang ditegakkan atas lima pilar itu dibuat oleh para sahabat. Sebab Nabi saw tidak pernah mempunyai suatu ungkapan khusus yang pasti diucapkan oleh orang-orang yang baru masuk Islam.

A'zami menyatakan syahadat dibaca setiapa tahiyat dalam shalat. Wensinck

${ }^{44}$ Dikutip oleh Syamsuddin Arif dari tulisannya, "Alter und Ursprung des Isnād," dalam jurnal Der Islam (1917-1918), h 44. 
justeru menuduh bahwa shalat itu baru selesai dalam bentuknya yang terakhir sesudah Nabi saw wafat. Menurut A'zami Aneh sekali pernyataan Wensinck, sebab al-Qur'n berkali-kali menyuruh untuk mengerjakan shalat, begitu pula Hadis Nabi saw yang menerangkan tentang shalat.

A'zami mengkritik mereka menggunakan pendekatan sejarah, khususnya sejarah hadis yang terdapat dalam naskah-naskah klasik. Di antaranya adalah naskah milik Suhail bin Abi Shaleh , Abu Shaleh (ayah Suhail) adalah murid Abu Hurairah sahabat Nabi . 


\section{Daftar Pustaka}

Abu Sahuw, Muhammad. al-Hadis wa al-Muhaddisun, Mesir, Matabah Mesr tth.

Anwar, Syamsul. Interkoneksi Studi Hadis dan Astonomi, Yogyakarta: Suara Muhammadiyah, 2011.

At-Tahdis: Journal of Hadith Studies, Vol. 1 No. 1 Januari-Juni 2017

Bik, Hudhari. terj. Mohammad Zuhri, Tarikh Tasyri' al-Islami, Semarang: Rajamurah-, 1980.

Bucaille, Maurice. Bibel, Qur-an, dan Sains Modern, Penerjemah H.M. Rasyidi,Penerbit Bulan Bintang, 1979.

Bukhari. shahih al-Bukhari, Maktabah salafiah, tp, tt.

Khatib, Muhammad 'Ajjad. al-Sunnah Qabla al-Tadwin, Beirut: Dar al-Fikr, 1989.

M. Echols, John dan Shadali, Hasan. Kamus Inggris Indonesia, Jakarta: PT Gramedia Pustaka, 2010.

Nadhiran, Hedhri, Periwayatan Hadis Bil Makna Implikasi dan Penerapannya Sebagai 'Uji' Kritik Matan Di Era Modern, Jurnal JIA/Desember 2013/Th.XIV/Nomor 2/187-207, hlm. 192

Prasetyo, Hendro. "Pembenaran Orientalisme Kemungkinan dan Batas-batasnya" dalam ISLAMIKA Jurnal Dialog Pemikiran Islam, Bandung: Mizan, 1994.

Qardhawi, Yusuf. Pengantar Studi Islam, Penerjemah Agus Suyadi Raharusun dan Dede Rodin, Bandung: CV Pustaka Setia, 2007..

Sahrodi, Jamali. Metodologi Studi Islam, Bandung: CV Pustaka Setia, 2008.

Siba'i, Mustafa. al-Sunnah wa Makânatuhâ fi tasyri' al-Islamî. al-Maktabah al-Islamî, 2000.

Sijistani, Abu Daud. Sunan Abi Daud, Juz Beirut: Dar al-Fikr, tth.

Sou'yb, Joesoef. Orientalisme dan Islam, Jakarta: Bulan Bintang, 1985.

Ujjad al-Khatib, Muhammad, Ushul al-Hadîts Ulumuhu wa Musthaluhu, Beirut: libanun. 1989.

Ya'qub, Ali Mustafa, Kritik Hadis, Jakarta, Pustaka Firdaus, 1995.

Zuhri, Muhammad bin Mathar. Tadwin al-Sunnah al-Nabawiyah, Riad: Maktabah Dar al-Minhaj, $1426 \mathrm{H}$. 